TITLE:

\title{
FURTHER RECORD OF SPADELLA ANGULATA TOKIOKA IN THE WESTERN NORTH PACIFIC
}

AUTHOR(S):

Tokioka, Takasi; Hamatani, Iwao

CITATION:

Tokioka, Takasi ... [et al]. FURTHER RECORD OF SPADELLA ANGULATA TOKIOKA IN THE WESTERN NORTH PACIFIC. PUBLICATIONS OF THE SETO MARINE BIOLOGICAL LABORATORY 1977, 23(6): 421-424

ISSUE DATE:

1977-03-25

URL:

http://hdl.handle.net/2433/175946

RIGHT: 


\title{
FURTHER RECORD OF SPADELLA ANGULATA TOKIOKA IN THE WESTERN NORTH PACIFIC ${ }^{1)}$
}

\author{
TAKASI TOKIOKA \\ Seto Marine Biological Laboratory \\ and \\ IWAO HAMATANI \\ Tennôji Senior High School of Ôsaka Kyôiku University
}

With Text-figures $1-2$

The benthic chaetognath, Spadella angulata Tokioka, was first described as a form of Spadella cephaloptera Busch in 1951 on five specimens found in the plankton samples collected in Nanao Bay near the middle of the Japan Sea coast of Honsyu Island, Japan (Tokioka, 1951). Later in 1964, it was raised to the rank of species on the examination of three specimens found in the plankton collection from the coastal waters of Malay (Tokioka and Pathansali, 1964). Further specimens were obtained in 1966 from the sandy floor, $50 \mathrm{~m}$ deep, off Seto Zaki $3.2 \mathrm{~km}$ south of the Seto Marine Biological Laboratory (Tokioka and Bieri, 1966) and recorded in 1968 from the Zostera belt in Tomioka Bay, Kyusyu Island (Kikuchi, 1968; p. 167).

The original specimens from Nanao Bay were 2.5 to $3.0 \mathrm{~mm}$ in length (inclusive of the tail fin) and characterized by the lateral fin extending anteriorly a little onto the trunk and the seminal vesicle that was provided with a prominence pointed forwards issued from the postero-lateral corner. In the specimens from the Malay waters, up to $4.1 \mathrm{~mm}$ in length, the seminal vesicle was devoid of any remarkable prominence, although the site for rupture was defined just the same as in the specimens from Nanao Bay and supported by a thickening foreshowing the prominence. The specimens from Sirahama were 4.4 to $5.8 \mathrm{~mm}$ long and their seminal vesicle roughly resembled that of the specimens from the Malay waters. Thus, there has been left a question whether the Malay specimens are really identical with the Japanese specimens or rather they represent a different form, as the two localities are apart from each other so far, without any records of occurrences of forms referable to this species from the vast waters between the mentioned two localities.

Recently in May 1975, a further collection of probably this benthic chaetognath was made by the last author on Yoron Island, a small island of the Amami Islands

1) Contributions from the Seto Marine Biological Laboratory, No. 636.

Publ. Seto Mar. Biol. Lab., XXIII (6), 421-424, 1977.

(Article 29) 
situated at approximately $27^{\circ} 01^{\prime} \mathrm{N} \times 128^{\circ} 24^{\prime} \mathrm{E}$. The close examination of this material was then made in a hope to fill up to some extent the above-mentioned deficiency in our knowledge.

The material includes 66 individuals from 0.7 to $2.3 \mathrm{~mm}$ in length (inclusive of the tail fin), consisting of 37 immature individuals less than $1.81 \mathrm{~mm}$ in length, 24 mature individuals longer than $1.81 \mathrm{~mm}$ and 5 intermediate ones from 1.69 to $1.88 \mathrm{~mm}$. The tail segment (inclusive of the tail fin) is always longer than the trunk, occupying 50 to $55 \%$ of the body length in most specimens and throughout smaller to larger individuals (Fig. 1). Eleven selected specimens from 1.4 to $2.1 \mathrm{~mm}$ in length were examined under the microscope. In these, the tail segment is 54.3 to 57.1 and $55.8 \%$ on an average. General features are nearly the same as in the specimens of

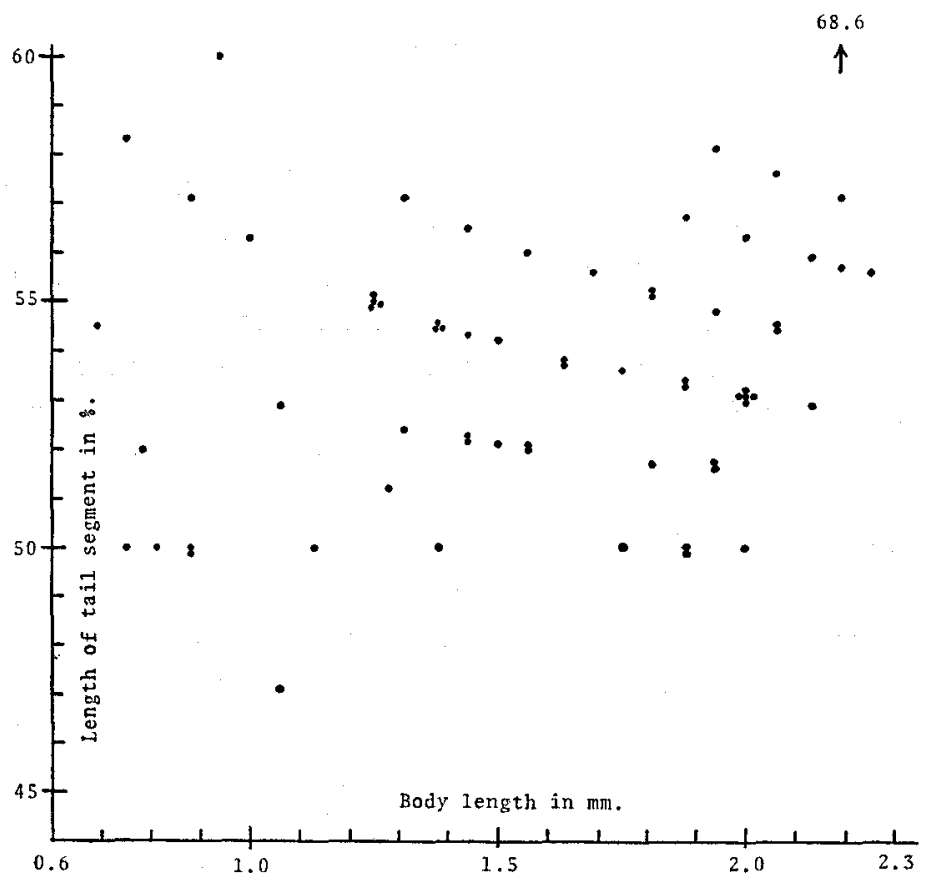

Fig. 1. Length of the tail segment in percent to body length (inclusive of the tail fin).

angulata previously described; the lateral fin furnished with rays throughout reaches anteriorly distinctly beyond the trunk-tail septum, this is seen especially clearly in the specimens with more or less worn frothy structure; the prominent cement gland found in S. cephaloptera at each genital aperture is wholly missing. The collarette is very distinct around the neck. The seminal vesicle is structured as in the Malay specimens (Fig. 2), with the site for rupture just anterior to the postero-lateral corner and a small thickening on the posterior margin of this place; the thickening might be corresponding to the prominent protuberance in the specimens from Nanao Bay, though 


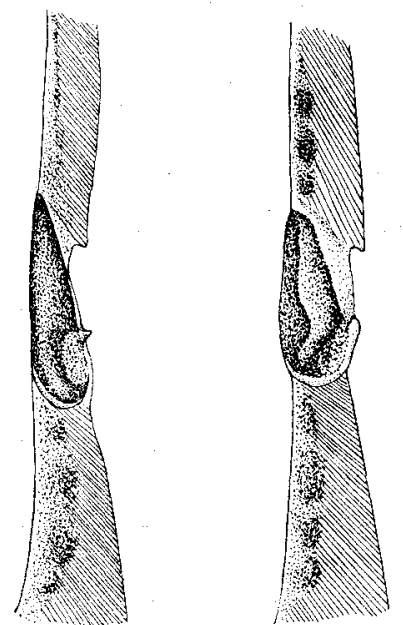

Fig. 2. Seminal vesicles of $2.1 \mathrm{~mm}$ long specimens, ventral. $\times 110$.

this is a very important point and still remaining uncertain. There are 5 to 7 small patches of possibly adhesive cells along the lateral side of the body in the posterior half of the trunk and in the anterior half of the tail segment respectively and a few to several of the similar patches anterior and also posterior to the seminal vesicle.

There are 6 hooks on each side, 7 hooks being counted only on one side of a single specimen. Anterior teeth up to 5, but no posterior teeth; number of teeth was read with certainty only in the specimens with hooks and teeth exposed, while it was very difficult to observe these exactly in the specimens with hooks wholly enclosed in the hood, in those only 1 to 3 teeth were counted.

Formulae confirmed in the specimens with the hood contracted and hooks and teeth exposed.

\begin{tabular}{cccc}
\hline $\begin{array}{c}\text { Body length } \\
\text { in mm }\end{array}$ & $\begin{array}{c}\text { Tail segment } \\
\text { in \%* }\end{array}$ & Hooks & Anterior teeth \\
\hline 1.4 & 57.1 & $6-6$ & $2-2$ \\
1.7 & 55.2 & $6-6$ & $3-4$ \\
2.1 & 56.2 & $6-6$ & $4-5$ \\
\hline
\end{tabular}

* inclusive of tail fin.

Seeing through these features, it will be noticed immediately that the specimens in the present material are significantly smaller than those from the localities known so far and are armed with fewer hooks, only 6 instead of 8 to 9 . At present, however, it is difficult to judge decidedly whether or not these characters are reflecting that the present material represents a separate form. It is probable, or rather proposed provisionally that the specimens from Yoron Island show an intraspecific type of angulata from oceanic localities, as $S$. cephaloptera previously recorded mainly from the 
continental coasts were recently collected by Owre (1972) from many oceanic localities in the Bahamas.

The specimens were collected from sand pockets with several centimeters deep sea water on the reef flat "Maéhama" along the southern coast of the island, by several repeats of filtration through a testing sieve with 145 meshes of rinsings of 500 to $1000 \mathrm{~cm}^{3}$ of sand from pockets. The nature of this habitat reminds us of that of S. cephaloptera in the Bahamas.

\section{REFERENCES}

Bieri, R. 1974. A new species of Spadella (Chactognatha) from California. Publ. Seto Mar. Biol. Lab., vol. 21, nos. 3/4, pp. 281-286.

Kikuchi, T. 1968. Faunal list of the Zostera marina belt in Tomioka Bay, Amakusa, Kyushu. Publ. Amakusa Mar. Biol. Lab., vol. 1, no. 2, pp. 163-192.

Owre, H. B. 1972. Marine Biol. Invest. Bahamas 18. The genus Spadella and other Chaetognatha. Sarsia, no. 49 , pp. $49-58$.

Tokioka, T. 1951. Pelagic tunicates and chaetognaths collected during the cruises to the New Yamato Bank in the Sea of Japan. Publ. Seto Mar. Biol. Lab., vol. 2, no. I, pp. 18-19.

Tokioka, T. and R. Bieri 1966. The colour pattern of Spadella angulata Tokioka. Publ. Seto Mar. Biol. Lab., vol. 14, no. 4, pp. 323-326.

Tokioka, T. and D. Pathansali 1964. Spadella cephaloptera forma angulata raised to the rank of species. Publ. Seto Mar. Biol. Lab., vol. 12, no. 2, pp. 145-148, pl. 5. 